\title{
Post-Colonial Girl-Children in Olive Senior's Short Stories
}

\author{
Begoña Vilouta Vázquez \\ University of Santiago
}

iabeviva@usc.es

\begin{abstract}
Three short stories by the Jamaican author Olive Senior deal with how difficult it is for a girl to grow up in post-colonial Jamaican society. From a post-colonial feminist stance, my analysis of the short stories considers how predetermined conceptions about race, colour, gender, or social class affect their protagonists as individuals. Their progress towards adulthood is deeply marked by the transference between two households, a rather common experience for Jamaican children. These changes of residence give Olive Senior the chance to explore the different and often opposing conceptions regarding issues such as race, language, social class, female sexuality, religion or marriage. The socialisation of girl-children is also influenced by the stereotype of the "angel of the house", a racialised construct characterised by silence, delicacy, and submissiveness. When it comes to physical appearance, paleness is one of the essential characteristics, referring to the superiority of white women. The construction of black women as Jezebels will be also analysed. The different conceptions about the aforementioned issues and the predetermined patterns of behaviour make it difficult for the protagonists to reconcile both worlds: one of the most common results shown by Senior is alienation and isolation. Girls usually end up not knowing where they belong.
\end{abstract}

The narrative perspective of the girl-child/adolescent is one of the main features O'Callaghan and Narain (1994) describe as a recurrent element in the works of the Anglophone Caribbean women writers among whom they include Olive Senior. One of the aims is to show the often alienating difficulties in the relationship between the adult world 
and the world of children. This perspective favours the study of the effects on the development of the protagonists of social hierarchies of race, class and gender derived from historical processes such as colonisation and slavery. We will see how the European patterns of behaviour taken to Jamaica by the English coloniser are instilled in girl-children from a very early age.

Olive Senior's short stories are usually concerned with childhood and with the construction of identity of child characters, especially female ones. "Bright Thursdays" (1986), "The Tenantry of Birds" and "The Two Grandmothers" (1989) share a common structure: the three female protagonists are presented at the centre of the narration, divided between two sets of conventions, two different conceptions of lifestyle.

The post-colonial feminist critical stance is the most useful approach to these short stories. Both theories share many common features: the political conception of literature, as a weapon to fight against social inequalities, the re-writing of history from previously silenced perspectives and the positive valuing of previously marginalised figures and literatures. Both literary theories question the existence of universal cultural values that can explain the experiences of different groups considered inferior by the centre, occupied by the male European coloniser:

Both are articulated by resistance to dominant authoritarian and neo-authoritarian orthodoxy and both speak from their position within the hegemonic language to subvert that language. But the most profound similarity is probably the extent to which both 'woman' and 'postcolonial' exist outside representation itself. For Luce Irigaray, woman is 'absence, negativity, the dark continent or at best a lesser man'. In patriarchal, phallogocentric culture the feminine and the postcolonial both exist in this dark chthonic region of otherness and non-being (Ashcroft, 1989: 23; my emphasis).

The identity of female subjects was constructed in a similar way to the identity of colonised peoples; both groups were defined in opposition to the group which occupies the centre. Both the patriarchal and the imperialist system base their power on biological constructions of society. Because they are the most visible ones, their physical features were used to relegate them to a secondary place in the social system, in a completely powerless position. Both women and post-colonial subjects have been predefined by Western patriarchal thought and certain patterns of behaviour and stereotypes have been applied to them. In Colonialism and Postcolonialism, Ania Loomba enumerates the features by which women and colonised peoples are defined from the point of view of the domineering Western patriarchal system:

...in the language of colonialism, non-Europeans occupy the same symbolic position as women. Both are seen as part of nature, not culture, and with the same ambivalence: either they are ripe for government, passive, childlike, unsophisticated, needing leadership and guidance, described always in terms of lack -no initiative, no intellectual powers, no perseverance; or on the other hand, they are outside society, dangerous, treacherous, emotional, inconstant, 
wild, threatening, fickle, sexually aberrant, irrational, near animal, lascivious, disruptive, evil, unpredictable (Loomba, 1998: 159-160).

bell hooks states that dominating systems share a common attribute: the existence of what she defines as "either/or dichotomous thinking" (quoted in Collins 68). Dichotomous thinking does not only establish a relationship of difference between the elements, but also one of opposition between them. What is more, objectification is considered central to this process of oppositional difference by hooks: "In either/or dichotomous thinking one element is objectified as the other and is viewed as an object to be manipulated and controlled" (quoted in Collins 69).

The construction of binary oppositions was one of the most powerful devices to organise and maintain power by colonial discourse. According to Edward Said, the expansion of imperialism was eased by the development of Orientalism, or the construction of colonised peoples as the Other. It may be defined as a discourse in the Foucaldian sense of the word: a manifestation of power/knowledge. Said emphasises the necessity to take this definition into account to understand how "European culture was able to manage - and even producethe Orient politically, sociologically, militarily, ideologically, scientifically, and imaginatively during the post-Enlightenment period" (Said, 1978: 3).

Bill Ashcroft defines colonial discourse as "the system of knowledge and belief about the world within which acts of colonisation take place" (1999: 68). However, what is more important for my analysis of the development of girl-children in Olive Senior's short stories is the way in which this discourse affects colonised peoples:

Aithough it is generated within the society and cultures of the colonisers, it becomes that discourse within which the colonised may also come to see themselves. At the very least, it creates a deep conflict in the consciousness of the colonised because of its clash with other knowledges of the world (1999: 68).

Olive Senior's fiction -mainly composed of short stories - can be inscribed within a literary movement taking place from the eighties onwards in the Anglophone Caribbean. Literature written by women in the English-speaking Caribbean is one of the most enriching contributions to contemporary literature. Anglophone Caribbean women writers place women's experiences at the forefront: life at home, pregnancies, the rearing of children, violence at home, prostitution, or marginalisation, that is, experiences regarded as specifically feminine representing the victimisation of women. At the same time, spaces previously considered as feminine are positively valued: the kitchen, the garden, domestic space in general. The aim is to show the arbitrariness of the images and values patriarchy has constructed as essentially feminine, codifying and distorting them as secondary and inferior. The predicament of colonised women is described by Gayatri Spivak: she depicts it as their disappearance "between patriarchy and imperialism, not into a pristine nothingness, but into a violent shuttling which is the displaced figuration of the "third-world woman caught between tradition and modernisation" (1993: 102). According to Carol Boyce Davies and Elaine Savory Fido in their landmark Out of the Kumbla, recovery of the 
voice has been one of the efforts made by Caribbean women writers in order to recreate and dismantle the past, to insert the silenced self into history.

The impact of colonial discourse on the protagonists of the short stories may be appreciated in every aspect of their lives. Socialisation of girl children is shown to be marked by the existence of restrictive gender roles depending on the interrelated categories of race, colour and social class. Female education is still influenced by Victorian ideology and Christian religion which aim at turning girls into good wives and mothers. They are taught gender-based roles and, as a result, they become unassertive, dependent, controlled and subservient to the male. Their development is affected by the transference between two households (a rather common experience in Jamaica), one in the country, one in town, both of them metaphors of the different cultural models existing within Caribbean society. Olive Senior alludes to "The Two Grandmothers" in a way I think is highly significant for the purpose of my analysis: "in a way, the story -the country and the city experiences-is really a metaphor for wider things, Jamaican life as a whole" (Glaser, 1994: 79).

The binary opposition town/country may be read from a referential and from a symbolic point of view. On the one hand, this dichotomy sets an opposition between country and town-dwellers as far as customs and cultural models are concerned. The eurocentric way of life with its subsequent appreciation of all things British (from the sixties and seventies everything that has to do with the United States) is placed against the areas where AfroCaribbean tradition is kept, creole language is spoken or different patterns of behaviour are regarded as valid or natural. The country usually offers many more opportunities for freedom than town, associated with behaviour rules and eurocentric standards. However, the vision of the country we are offered is not an idealistic one. Senior shows both the increasing influence of European and American standards and the repressive character of Christian religion. On the other hand, the difficult relationship between the two realms alludes to the binary opposition centre/margins, ruler/ruled, white/black, man/woman established between the metropolis and the colonies, whereby colonised people were considered inferior, feminine, immoral, lacking agency and needing guidance. The three short stories treat one family as a microcosm of conflicting gender, class, and race conceptions which represent society in general. Olive Senior describes this situation as autobiographical:

In being constantly shifted between two households I think I was also pretty much being shifted between the two extremes of a continuum based on race, colour and class in Jamaica. The village was largely black and strongly African in character, the whole folk culture was very strong there. (...) At the other extreme was my 'adopted' family which represented the European element in Jamaican culture. In that world I was socialised to respect European values exclusively. People in Jamaica who were light-skinned, white, near white, in those days looked down on people who were black, who were African and, as part of that process, they also 'low-rated' or discounted the indigenous culture of Jamaica. So all this made very difficult to shift between the two worlds, because they represented the two extremes, the polarities of colonial society. (Rutherford, 1986: 12). 
The different cultural models mark the process of growing up in a post-colonial or neocolonial society like Jamaica and conceptions on issues such as gender, female sexuality, race, colour, social class or language. The difficult relationship between both realms leads to a tension between 'real' and 'ideal' behaviour the latter being the model imposed by the coloniser, situation described by Merle Hodge as

the discrepancy between school and home, between the culture of books, newspapers and religious instruction and the culture practised by the adults with whom the child is most intimately involved and who are responsible for the transmitting to the child the mores of the tribe: mother, grandmother, aunt (quoted in Senior, 1991: 41).

Many of Senior's short stories in the three collections published so far present protagonists who are not able to understand the social codes, conventions, or preestablished patterns of behaviour which rule the world of older generations. This is especially true in the case of "The Two Grandmothers". Each grandmother represents one of the realms I have described. Its structure is particularly helpful to analyse the short story because the seven sections present alternatively the protagonist's conversations with her mother, which are full of questions and doubts about the things she cannot understand in her visits to each of her grandmothers.

We may define the protagonists as displaced ${ }^{1}$ children because as they travel physically from country to town or vice versa, they feel they do not have a place in either of the two. The protagonists end up feeling torn inside and alienated and as a result, they suffer a crisis in their self-image. Laura, the central figure of "Bright Thursdays", lives in a rural area with her mother and brothers. The conflict comes when she is "permanently transported from her mother's two-room house to this mansion of her father's" (p.44). Once there, her uneasiness and feeling of unbelonging are constantly presented and symbolised by the lack of space for her in the dining room table: "When they were all seated, they fitted so neatly in their slots that there was no space allotted for her" (p.37). The Watsons may be defined as mimic ${ }^{2}$ as their way of life is a repetition of the English Victorian model rooted in European gender and class conventions which was taken to the West Indies by the colonisers. Henriques (1976) asserts that the model of European society exemplified by the upper class - composed mainly of fair coloured people-- is seen as the ideal by middle class people. Therefore, they reject the behaviour of the people from the lower classes. The Christian, monogamous paternalistic family is the fundamental unit of the middle class family. Kathleen Renk (1999) highlights family, school and the family house state as the three shrines of enlightenment which transmitted Victorian ideology. The ideal bourgeois family pattern should be imitated by "good" creole colonials, who copied English dress, attitudes, disposition, and fundamental values peculiar to the colonisers. According to Renk, these images transmitted by the prevailing ideology "became the interior landscape of the colonised mind" (1999: 32).

Two ideas of the family are opposed, the real one and the ideal one. The former is described by Merle Hodge: 
...in our family systems the head of the family can be female or male; legal marriage is not mandatory; the family spills beyond one household to include cousins, aunts and uncles, grandparents and even godparents as functional members of the family (1990: 205).

This description corresponds to Laura's first home. Her mother is the head of the family, is not married and has had some children from different men. The ideal model of the family is represented by the Watsons, and by the parents of each of the protagonists of "The Tenantry of Birds" and "The Two Grandmothers"; their family conforms to the mythic colonial Victorian model which consists of "the moral and intellectual father, the angelic, asexual mother, and the dutiful child whose character has been shaped by the moral strength of his/her parents" (Renk, 1999: 8). A patriarchal realm is offered to the protagonist of "Bright Thursdays", who must become a part of this ideal family. Although he is not present, the figure of a protective father looms large over Laura because, from the very beginning of her life, her mother makes up an 'ideal' father figure for her: "For years, Miss Myrtle sustained herself with the fantasy that one day Laura's father would miraculously appear and take her off to live up to the station in life to which she was born" (1986: 39).

The myth of the ideal family presented as perfect goes back to the nineteenth century, although it has survived and been put in practice by the Caribbean people up to these days. Rationalisation of time, rigid timetables for each of the household chores, the chiming of clocks, the tinkling of bells announcing meals, the obsession with cleanliness and white clothes, in general the importance of rituals points to what Anne McClintock calls "the Victorian cult of domesticity" consisting of "the middle class determination to identify happiness with rational order and the clear demarcation of boundaries [which] manifested itself in precise rules not only for assembling the public sphere but also for assembling domestic space" (p.168). Ritualisation of family life is felt by the protagonist as something strange, placed against the naturalness and lack of constrictions of her previous house. The mythic aspect of the family was reinforced by the association of the house with an enclosed garden, "a place of serenity overseen by the "queen of the garden'" (Renk, 1999: 30). Thus, the Watsons' house becomes a sacred place, some sort of church-"The Table ${ }^{3}$ was in the Dining Room and at least twelve could have comfortably sat around it" (1986: 37) -which cannot be tainted by anything that may be considered impure according to the Watsons' social status: "she instinctively knew after a while that she would never in this place find anyone good enough to bring into Miss Christie's house" (p.47).

Laura's physical features (soft skin, curly hair and straight nose) are her passport to enter her father's family. It is in this aspect that race, gender, and social class are tightly interrelated. Once the possibility of going to her father's mansion is confirmed, her training according to her gender role begins. Her mother's expectations to see her daughter rise from the lower to the middle class imply teaching her useful housekeeping tasks, cleanliness or European norms. Both in this short story, and in the other two, the protagonists' identity is constructed to become 'ladies' according to the stereotype known as the angel of the house. Duality operates in the construction of the identity of female protagonists because models of female sexuality involve an either/or choice between the Virgin/whore stereotypes which are also related to race and class hierarchies. Ascent in the social ladder 
involves for Laura the rejection of her mother's way of life (unmarried motherhood and a certain degree of sexual freedom) and the "emulation of the Virgin Mary" (O'Callaghan, 1993: 42), a model of behaviour she finds in her grandparents' house in the figure of her grandmother and her father's wife, a white yellow-haired woman. Senior describes this stereotyped behaviour as follows:

the model for 'right behaviour' for women in the Caribbean was an imported one-the model which emerged elsewhere in Western society: that of woman as a being whose purpose is derived from the existence of another, whether husband, father, or extended family, and whose locus is the home or household. In Jamaica we also get the physical property of the image: a woman "pale and delicate" (1991: 41).

Women whose behaviour deviates from the norm are constructed as negative examples for girl-children and disregarded as jezebels. As stated by bell hooks, the creation of the figure of the jezebel runs parallel to the change in attitude of white men towards white women in the nineteenth century. The development of the construct of the virtuous lady brought about determining consequences for the moral assessment of black women: "As white colonisers adopted a self-righteous sexual morality for themselves, they even more eagerly labelled black people sexual heathens. ... They were labelled jezebels and sexual temptresses and accused of leading white men away from spiritual purity into sin" (1982: 33).

Those who have children without being married are stigmatised and marginalised by the representatives of Christian morality. Their sexual behaviour is interpreted as distorted and constructed as deformed because they challenge the oppressive society conventions. That is what happens in "The Two Grandmothers": Eulalie and Ermandine are two sisters whose children were born outside marriage, and therefore, labelled as fallen by the protagonist's grandmother in the country. Myrtle, Laura's mother in "Bright Thursdays" is alluded to as 'uppity black gal' (1986: 40) by Mrs Watson, another representative of the morals of Christian religion, which regard marriage as the only morally valid sexual union.

Household chores are divided between Laura and her brothers and those to be performed inside are reserved for her. Seclusion, then, has a twofold objective: educating her as a housewife and also preventing her skin from getting burnt. It is at this moment when she feels alienation for the first time. The constrictions she is going to feel at the Watson's are anticipated by her mother's training at home. Something similar happens in "The Tenantry of Birds". From her childhood Nolene's identity is constructed so she fits this predetermined pattern of behaviour: from her physical appearance to her use of English, she is headed for a marriage that will be arranged by her mother and separated from everything that has to do with blackness or Afro-Caribbean culture. This stereotype led to the denial of cultural practices closely related to Afro-Caribbean women such as Anansi stories, duppy stories or folk songs. Colonial repression is then attached to patriarchal repression, which constructs feminine identity with silence as one of its fundamental principles. A very long flashback establishes an opposition between the freedom felt in the country with her cousins and the pressure felt in town under her mother's thumb in Kingston: "she felt herself restricted, as if she were not a person in herself but a creation, 
an extension of her mother, she was a presence which she could not shake off long enough to express herself, to be" (1989: 50). As I stated before, gender-role learning leads to the construction of girl-children as unassertive, dependent, servile or controlled. Thus, her education turns Nolene into a character whose main feature is her silence and her lack of autonomy. In fact, she is alluded to as 'dutiful' on many occasions: "dutifully doing what her mother, her teachers told her..." (p.52) or "And though she dutifully tried..." (p.55) The identity that has been constructed for her grants a feeling of security that prevents her from thinking and deciding for herself. The different gender-roles provided by her education - daughter, wife, mother-are her kumbla, term used by Erna Brodber in Jane and Louisa Will Soon Come Home and defined as "a protective device" (p.130) and further explained by Elaine Fido: she defines it from a referential point of view as a "calabash pot Jamaican women used to store things" (1988: 342). From a symbolic point of view the kumbla represents "the protection given to women in their domestic role which also confines them: getting out of the kumbla is then essential" (342).

It is in the country that Nolene's 'crucial moments of being' (Donnell, 1999: 121) take place as she feels her mothers' prejudices need not exist. It is there that she feels a freedom she is denied in town. Mr Chin's shop, a forbidden place, which seems to sum up all her mother's restrictions, is the place where she feels free and achieves a positive sense of herself: "In the shop she felt happy as if there was nobody looking over her shoulder to see what she was doing" (1989: 51). These experiences, which are defined by Alison Donnell as 'acts of resistance' (1999: 124) come about away from colonial dominance and will be determinant for the renegotiation of her identity as a Jamaican woman years after. Staying in the country gives her the possibility to explore her feelings as she is liberated from the young lady or proper person rituals imposed on her by her mother in town. This freedom, which is repressed and thwarted by the necessity to conform her physical aspect to the eurocentric model, is felt in the country. The protagonist's body is a meaningful symbol of the different conceptions regarding her education. An opposition is set between her body in the country and in town. The village, where she feels free, produces a body that is different from the body in town, where, instead of belonging to her, it belongs to her mother. Her body is implicated in power relations between the sexes as well as among women. Not only hers, but also Laura's, are used by the dominating culture to define and stigmatise them as subjects. Colonial discourse as a form of power is exercised on and through female bodies. Blackness is seen as a sign of victimisation and powerlessness, and, as a result, the body must be disciplined to make it fit into Eurocentric standards. bell hooks defines these as silenced bodies, that is, they cannot challenge the "assumptions that the black body, its skin color and shape, is a mark of shame" (1992: 68).

Female bodies become a theatrical site on which these two competing discourses and ideologies fight for supremacy. According to Michael Dash, the body becomes one of the major symbols of the process of subjectification in Caribbean literature. The tension between the two conceptions of reality I have already mentioned is expressed by a system of imagery with the colonised people's body at its centre: 
Corporal imagery in the Caribbean indicates the tensions that underlie the process of self characterisation, of the "rècupèration de soi" in the individual imagination. The ever shifting, unstable relationship between body and non-body, between dis-membering and re-membering is a continuous and thematic concern (Dash, 1989: 20).

After visiting her family in the country, the girl's body, her hair, and more importantly her skin, show traces of negritude that must be erased in order to re-enter the middle-class world her mother inhabits:

...look at her hair it was just cane trash and full of knots and look at all the scratches and scabs on her knees and elbows and she hadn't cleaned her ears once (...) and was talking badly just like those country children. She was tired of correcting her and worst of all her skin was burnt black and it would take weeks and weeks to get her complexion fair and clear again (1989: 52).

Colour is a highly complex issue in Jamaican society. Once more, the ideal model has nothing to do with reality. Although the relationship colour/social class is not so rigid nowadays because money has become the main condition for upward mobility in the social scale, in "Bright Thursdays", the relationship with a lighter man is seen by Laura's mother as a way of achieving social advantages for her child. Fanon has defined Myrtle's behaviour and aspirations as a constant in Caribbean societies:

Whiten the race, save the race, but not in the sense that one might think: not 'preserve the uniqueness of that part of the world in which they grew up,' but make sure it will be white.... The number of sayings, proverbs, petty rules of conduct that govern the choice of a lover in the Antilles is astounding. It is always essential to avoid falling back into the pit of nigerhood, and every woman in the Antilles, whether in casual flirtation or in a serious affair, is determined to select the least black of the men (1982: 47).

Jamaican individuals still associate skin colour with class hierarchies which have to do with the legacy of slavery. Shade nuances are also used as a scale, and thus light brown skin ranks better than brown and black ones. Whiteness and the Caucasian model are associated with beauty, whereas blackness and its traces (kinky hair or broad noses) are signs of ugliness. Ana Bringas (2000: 139) states that the idea of "raising the colour" or "lightenen of de cawfee" has been associated in Caribbean fiction with men whose main objective is getting married to white women in order to ascend the social ladder. Bertram, Laura's father, comes back with a white woman who is completely opposed to Laura's mother. Men see the relationship with a white woman as a step towards complete integration in white society. As Fanon (1982: 63) has described, his new wife represents his achievement: integration in white culture is symbolised by the marriage to a white woman.

I wish to be acknowledged not as black but as white. Now -and this is a form of recognition that Hegel had not envisaged- who but a white woman can do this for me? By loving me she 
proves that I am worthy of white love. I am loved like a white man. I am a white man. ... I marry white culture, white beauty, white whiteness.

For Caribbean women, the closest approximation to this ideal is considered a vantage point for the achievement of a successful marriage. White skin (or as light as possible), straight hair or blue eyes privileges women in a system in which part of the basic definition of whiteness is its superiority to blackness. Therefore, there is a strong desire to achieve this ideal. That is why self-esteem depends greatly on satisfaction with colour. This is one of the key elements which work against Laura's self-appreciation at the Watsons'. Her colour, which is on some occasions defined as "too dark" and her humble origin lower down her concept of herself as she sees the photographs of the other Watson's grandchildren and, as a result, she refuses to acknowledge her own identity: "All that she saw was a smiling face that in some indefinable way looked like all the faces in the other photographs. All were bland and sweet. Faced with such perfection, she ceased to look at herself in the mirror" (p.44). Her sense of unbelonging to the middle-class world is symbolised by the clouds which remind her of Jesus' coming to judge her for her social inferiority. Comparing themselves with the European model of beauty is, on the word of Frantz Fanon, one of the deepest preoccupations of Caribbean people. The belief that they should try to look like Europeans as much as possible is always present.

The Negro is comparison.... that is, he is constantly preoccupied with self-evaluation and with the ego-ideal. ... The Antilleans have no inherent values of their own, they are always contingent on the presence of the Other. The question is always whether he is less intelligent than I, blacker than I, less respectable than I. Every position of one's own, every effort at security, is based on relations of dependence, with the diminution of the other $(1982: 211)$.

According to Hershel (1997), gender expectations are transmitted in the family realm and the societal gaze plays a more significant role in adolescent identity formation and is focused to a greater extent on race. However, race may become an internal family argument when the child's race is put into question especially because of lack of acceptance by the extended family or if determination of how light- or dark-skinned the child is a factor. This is the case of our protagonists, especially in the case of Laura and the protagonist of "The Two Grandmothers". The shade of their skin is a source of constant argument in their families and it ends up affecting their self-esteem, that is, "a measure of internal selfcohesiveness that underlies the ability to function with ease in the world" (Hershel, 1997: 110). Especially in "The Two Grandmothers", the different remarks made by each grandmother are antithetical and end up affecting the child. She is lighter than the other people in the country are, but too dark according to the standards of her grandmother in town. Her grandmother's admiration of her skin -"Grandma Del says my skin is beautiful like honey and all in all I am fine brown lady and must make sure to grow as beautiful inside as I am outside..." (1989: 64) - is later contradicted by her other grandmother: "She always seems angry about it and Joyce says Grandma is sorry I came out dark because she is almost a white lady and I am really dark" (p.67). The tension I mentioned before culminates when 
a racist remark made by one of her lighter cousins leads her to be ashamed of herself and even doubt about her own identity. The constant questions ("am I really black?" or "How can I be beautiful?") she asks at the end of the short story show how her family's problems with her colour finally affect her conception of herself.

The imposition of these standards leads the protagonists to reject anything that has to do with the country and with Afro-Caribbean culture. Laura, in "Bright Thursdays" establishes an opposition between her mother and her father's wife, which includes some of the parameters I have dealt with previously. The association of blackness with ugliness I have mentioned before leads her to despise her mother, including her use of creole as an element which debases her: "Looking at her long polished nails, Laura had a picture of her mother's hands, the nails cracked and broken from her work in the fields; of her mother's dark face, her coarse shrill voice. And she was bitterly ashamed" (p.52).

Two of "The Two Grandmothers" sections, the first and the fifth ones, show the change of opinion of the protagonist about the country and Grandma Del. If the first section showed the girl's idealisation of the village, the fifth one presents her as completely alienated from the rest of the people there. Her integration in the community is symbolised by the walks to church with the village people: "...I walk home with [Grandma Del] and all the people, it's so nice" (p.63). Years after, she refers to them as "all these stupid people" or she says "there's nobody but black people where Grandma lives" (p.72). She also despises her grandmother's house in the fifth section. It is defined as "small, crowded and dark" (p.71), while in the first section it was "nice and cosy and dark and cool" (p.63). The influence of television, defined by Merle Hodge as a "Trojan horse" (1990: 204), destroys the connection oral tradition had established between grandmother and granddaughter in the first section: "I am going to learn stories from Grandma so when I am an old lady I will remember all these stories to tell my children" (p.64).

The protagonists' transformation indicates the power of the ideology that affects every aspect of their lives in Jamaica. Ideological forces are not merely an influence: their identity as subjects is literally constructed by them. Althusser's notion of interpellation or "the hailing of the subject" is especially useful to understand the process through which they are formed as subjects by powerful forces working in the interest of the prevailing ideology in colonial society. Individual subjects come into being within a pre-existing ideological structure which transmits the individuals what they should be like: "All ideology has the function of constituting concrete individuals as subjects - of enlisting them in any belief system, according to Althusser. That's the main thing ideology as structure and ideologies as specific belief systems do- get people (subjects) to believe in them" (Klages 2001). However, in colonial societies, there is always a gap between what ideological forces transmit and what individuals find in everyday reality. The feeling that they will never achieve the standards regarded as the proper ones leads on many occasions to alienation and frustration. They are interpellated as true British subjects; however, at the same time, they are distanced by the motherland, which creates "a subject of difference that is almost the same, but not quite" (Bhabha, 1984: 126). 
As I have stated before, the structure of the short stories is similar: there comes a point when the protagonists' development involves for them a choice between the two different ways of life they have experienced. Again, this choice may be read as a symbol of the options Jamaican society faces, either outside influence from the United States or the achievement of cultural sovereignty. Self-empowerment of children comes when they are able to decide for themselves and in Senior's own words, "to create self-identity out of a personal chaotic history" (Thieme, 1994: 91). In "The Tenantry of Birds" and "Bright Thursdays", the protagonists are able to escape from the constrictions and expectations imposed on them, especially by their mothers. It is a common element in Senior's short stories to show how self-empowerment comes from the acknowledgement of alternative cultural practices despised and underestimated by colonial education.

For Nolene, going back to Jamaica means returning to the past when she spent the summer in the country with her cousins. It means recovering a paradise lost which is at the same time a recuperation of her self and a cry for freedom, key element for the construction of her new identity as a Jamaican woman. Her final words "Green Bush. Green Bush. Green Bush" (1989: 61) articulated as an exorcism are a metaphor for the cultural practices she knew there as a child and which had been forbidden for her until then.

For Laura, rejection of her mother's expectations frees her from the anguish she feels because of her social inferiority. A harsh commentary of her father's puts an end to the fantasy created by her mother and sets her in motion. The first step for the construction of her new identity is to make herself an orphan. Renouncing her dreamed father and the advantages of the middle-class world means escaping from the alienating relationships she felt there and from the guilt she feels for not being good enough to fit in the Watsons' household. The clouds which symbolised her sense of inferiority and unbelonging dissipate at the moment when she refuses to be one of the members of the patriarchal colonial realm her father's mansion represents. On the contrary, the ending of "The Two Grandmothers" is the opposite one. The protagonist finally chooses to get away from her Afro-Caribbean heritage, from her grandmother in the country and the part of her family that she represents. The ending of this short story alludes to the difficulties which characterise the construction of the identity of Jamaican girl-children.

These three short stories expose how the different competing discourses influence to a great extent the construction of the characters' identity and also how the overlapping categories of colour, gender and class are channelled into confusing subject positions. Searching for their identity as Jamaican women means making the effort to negotiate the conflict existing between the different polarities that have predefined their existence. Laura and Nolene are able to renounce the privileges and the comfortable way of life represented by the middle class, which at the same time, oppresses and alienates them as black women. By contrast, the ending of "The Two Grandmothers" shows how the binary opposition existing between a despised black and an overvalued white way of life makes it easier for the protagonist to let herself be led by the mainstream of American influence. However, as Senior herself has put it, "...those very same people in later life come to realise-come to 
appreciate-the real culture, the traditional culture. So I guess there is hope for her" (Glaser, 1994: 84).

\section{Notes}

1. The use of the term "displacement" is related to the description of the themes dealt with in post-colonial literatures made by Ashcroft, Griffith and Tiffin in The Empire Writes Back (1989: 9). They associate it with terms such as "cultural denigration", "crisis of identity", "dislocation", "crisis in self-image"; most of them can be applied to the situation lived by the protagonists of the short stories during their development.

2. Bhabha calls their behaviour "flawed colonial mimesis" doomed to be incomplete, because, as colonists of colour, they are "almost the same but not white" (1984: 130)

3. Note the use of capital letters when dealing with domestic elements which acquire religious status and the reference to the twelve apostles of Jesus, who might be sitting around the Watsons' dining room table.

4. The Jamaican middle-class love for anything British is directly related to the hate they feel for anyone who makes them remember who they really are. Something similar happens in Hazel D. Campbell's short story "Don't Colour Me" included in her collection Singerman (1991) Yorkshire, Peepal Tree.

\section{Works cited}

Ashcroft, W. D. (1989): "Intersecting Marginalities: Postcolonialism and Feminism". Kunapipi XI. 2. 23-35

Ashcroft, Bill, Gareth Griffiths and Helen Tiffin, eds. (1989): The Empire Writes Back. Theory and

Practice in Post-Colonial Literatures. London and New York: Routledge.

Ashcroft, Bill and Pal Ahluwalia (1999): Edward Said: the Paradox of Identity. London: Routledge.

Bhabha, Homi (1984): "Of Mimicry and Man: The Ambivalence of Colonial Discourse". October 28. Spring 1984, 125-134.

Bringas López, Ana (2000): Muller e Literatura na Sociedade Caribeña Anglófona. Vigo: Servicio de Publicacións Universidade de Vigo.

Brodber, Erna (1980): Jane and Louisa Will Soon Come Home. London: New Beacon.

Collins, Patricia Hill (1991): Black Feminist Thought: Knowledge, Consciousness and Empowerment. London and New York: Routledge.

Dash, Michael (1989): "In Search of the Lost Body: Redefining the Subject in Caribbean Literature". In Slemon, Stephen, and Helen Tiffin, eds., After Europe. Mundelstrup: Dangaroo Press, 17-26.

Davies, Carol Boyce and Elaine Savory Fido, eds. (1990): Out of the Kumbla. Caribbean Women and Literature. Trenton: Africa World Press.

Donnell, Alison (1999): "The Short Fiction of Olive Senior". In Condé, Mary and Thonunn Lonsdale, eds., Caribbean Women Writers: Fiction in English. Basingstoke and London: Macmillan, 117-143.

Fanon, Frantz (1982): Black Skin, White Masks. Trans. C.L. Markham. New York: Grove Press (Peau Noire, Masques Blancs. $1^{\text {st }}$ edition, 1952). 
Fido, Elaine Savory (1991): "Where Do We Go From Here? Literature in English and the Women's Studies". In Mohammed, Patricia, and Catherine Shepherd, eds., Gender in Caribbean Development. Kingston: Institute of Social and Economic Research, 333-344.

Glaser, Marlies (1994): "A Shared Culture'. An Interview with Olive Senior". In Glaser, Marlies, and Marion Pausch, eds. Caribbean Writers: Between Orality and Writing/Les Auteurs Caribéens: entre l'oralité et l'écriture. Amsterdam: Rođopi, 77-84.

Henriques, Fernando (1976): Family and Colour in Jamaica. London: Granada.

Hershel, Helena Jia (1997): "The Influence of Gender and Race Status on Self-esteem during Childhood and Adolescence". In Zack, Naomi, ed., Race/Sex: Their Sameness, Difference and Interplay. New York and London: Routledge, 109-116.

Hodge, Merle (1990): "Challenges of the Struggle for Sovereignty: Changing the World versus Writing Stories". In Cudjoe, Selwyn, ed. Caribbean Women Writers: Essays from the First International Conference. Massachusetts: Calaloux, 202-208.

hooks, bell (1982) Ain't I a Woman: Black Women and Feminism. London: Pluto Press. . (1992) Black Looks: Race and Representation. Boston: South End Press.

Klages, Mary 15.06.2002: "Louis Althusser's 'Ideology and Ideological State Apparatuses"" http://www.colorado.edu/English/ENGL2012Klages/index.html

Loomba, Ania (1998): Colonialism / Postcolonialism. London and New York: Routledge.

McClintock, Anne (1995): Imperial Leather: Race, Gender and Sexuality in the Colonial Contest. London and New York: Routledge.

Narain, Denise de Caires and Evelyn O'Callaghan (1994): "Anglophone Caribbean Women Writers". Kunapipi XVI.1 Special Issue: Post-Colonial Women's Writing, 625-630.

O'Callaghan, Evelyn (1993): Woman Version: Theoretical Approaches to West Indian Fiction by Women. London: Macmillan.

Renk, Kathleen J. (1999): Caribbean Shadows and Victorian Ghosts. Charlottesville and London: University Press of Virginia.

Rutherford, Anna (1986): "Olive Senior: Interview". Kunapipi VIII, 35-44.

Said, Edward (1978): Orientalism. New York: Vintage.

Senior, Olive (1986): Summer Lightning and Other Stories. Harlow: Longman. . (1989): Arrival of the Snake Woman and Other Stories. Harlow: Longman.

. (1991): Working Miracles: Women's Lives in the English-speaking Caribbean. London: James Currey Ltd.

Spivak, Gayatri Chakravorty (1993) "Can the Subaltern Speak?". In Williams, Patrick and Laura Chrisman, eds. Colonial Discourse and Post-Colonial Theory: A Reader. New York: Harvester Wheatsheaf, 66-111.

Thieme, John (1994): "Mixed Worlds: Olive Seniors Summer Lightning". KunapipiXVI.2, 90-95. 